Check for updates

Cite this: RSC Adv., 2019, 9, 9030

Received 8th January 2019

Accepted 5th March 2019

DOI: $10.1039 / c 9 r a 00165 d$

rsc.li/rsc-advances

\section{Study on the hydrogen production ability of high- efficiency bacteria and synergistic fermentation of maize straw by a combination of strains}

\author{
Hongxu Bao, ${ }^{\text {abc }}$ Xin Zhang, (DD ab Hongzhi Su, ${ }^{a}$ Liangyu Li, ${ }^{a}$ Zhizhong Lv ${ }^{a}$ \\ and Xinyue Zhang ${ }^{a}$
}

Based on the principle of reciprocal symbiosis and co-metabolism of mixed culture microorganisms, a group of high-efficiency maize straw-degrading hydrogen-producing complex bacteria X9 + B2 was developed by a strain matching optimization experiment. Systematic research and optimization experiments were carried out on the mechanism of the main controlling factors affecting the hydrogen production of the complex bacteria. The results showed that the optimum conditions for the acid blasting pre-treatment of maize straw as a substrate were as follows: when the inoculation amount was $6 \%$ and the inoculum ratio was $1: 1$, at which point, we needed to simultaneously inoculate, the initial $\mathrm{pH}$ was 6 , the substrate concentration was $12 \mathrm{~g} \mathrm{~L}^{-1}$, and the culture time was $40 \mathrm{~h}$. The complex bacteria adopted the variable temperature and speed regulation hydrogen production operational mode; after the initial temperature of $37^{\circ} \mathrm{C}$ for 8 hours, the temperature was gradually increased to $40{ }^{\circ} \mathrm{C}$ for 3 hours. The initial shaker speed was $90 \mathrm{rpm}$ for 20 hours, and the speed was gradually increased to $130 \mathrm{rpm}$. The maximum hydrogen production rate obtained by the complex bacteria under these conditions was $12.6 \mathrm{mmol} \mathrm{g}{ }^{-1}$, which was 1.6 times that of the single strain $\mathrm{X} 9$ with a maximum hydrogen production rate of $5.7 \mathrm{mmol} \mathrm{g}{ }^{-1}$. Through continuous subculturing and the $10^{\text {th }}, 20^{\text {th }}, 40^{\text {th }}$, $60^{\text {th }}, 80^{\text {th }}, 100^{\text {th }}$ and $120^{\text {th }}$ generation fermentation hydrogen production stability test analysis, no significant difference was observed between generations; the maximum difference was not more than $5 \%$, indicating better functional properties and stability.

\section{Introduction}

Fermenting bacteria and photosynthetic bacteria are microorganisms that are mainly used in the field of hydrogen production. ${ }^{1}$ It is generally believed that the efficiency of hydrogen production by fermenting bacteria is higher than that by photosynthetic bacteria. However, there are still great differences when pure cultures or mixed cultures are adopted. The fundamental reason is that it is not clear whether the synergy between the strains is conducive to hydrogen production during mixed culture. ${ }^{2,3}$ From the microbial ecological analysis, the synergistic effect of mixed strains is essentially a reciprocal symbiotic relationship between the bacteria, and it plays an important role in biodegradation. Feedback inhibition and population function have become an indisputable fact.

${ }^{a}$ School of Environmental Science, Liaoning University, Shenyang 110036, China. E-mail: baohongxu555@163.com; Fax: +86024 62204818; Tel: +8602462202248

${ }^{b}$ Key Laboratory of Pollution Ecology and Environmental Engineering, Institute of Applied Ecology, Chinese Academy of Sciences, Shenyang 110016, China

'State Key Laboratory of Urban Water Resources and Environments, Harbin Institute of Technology, Harbin 150090, China. E-mail: waj0578@hit.edu; Fax: +86 451 86282195; Tel: +8645186282195
However, regarding the synergistic effect of the complex microflora in the process of hydrogen production, due to the large difference between the experimental conditions and the hydrogen-producing bacteria, there is still no clear and unified explanation at research and abroad. ${ }^{4-7}$

At present, research on microbial hydrogen production technology is generally based on the analysis of the hydrogen production efficiency of a single type of micro-flora. Samson isolated a facultative bacterial strain and used corn stem hydrolysate as the sole carbon source for hydrogen production of $0.91 \mathrm{~mol} \mathrm{H}_{2} / \mathrm{mol}$ glucose. ${ }^{8}$ Li produced hydrogen by the simultaneous saccharification and fermentation of steamexploded corn straw (SECS) using Clostridium butyricum AS1.209. ${ }^{9}$ Hydrogen production studies of the complex flora of the system are often only directed toward a part of the hydrogen production process. Noike and Mizuno ${ }^{\mathbf{1 0}}$ intermittently produced hydrogen by using rice husk with $1.73 \mathrm{~mol} \mathrm{H}_{2} / \mathrm{mol}$ hexose, $2.54 \mathrm{~mol} \mathrm{H}_{2} / \mathrm{mol}$ hexose, and rice shell with $1.29 \mathrm{~mol}$ $\mathrm{H}_{2} /$ mol hexose. Qiu ${ }^{11}$ conducted a batch test to study the effect of temperature on the hydrogen production of xylose using a mixed culture over a wide temperature range. The results showed that several microbial community structures were formed under different temperature conditions, resulting in 
different metabolic pathways for xylose and hydrogen production capacity.

Combined with the compounding principle of the complex flora, the single bacteria can be combined and cultured, which is beneficial to the formation of a complete enzyme system and enhance the ability of cellulose degradation and hydrogen production. ${ }^{12-14}$ This requires a large number of compound experiments to observe and screen the combination of high cellulose degradation activity and hydrogen production capacity. ${ }^{15,16}$

Three kinds of pure strains, namely ethanol-type fermentation hydrogen-producing bacteria (B2, B19, B49), butyric acidfermenting hydrogen-producing bacteria (C3) and butyric acid-degrading cellulose hydrogen-producing bacteria (X9, $\mathrm{X} 12$ ), were selected for the hydrogen production test. The degradation hydrogen production rate of each formulation was used to evaluate and determine the best combination of hydrogen-producing bacteria for degrading maize straw. A group of high-efficiency maize straw degrading hydrogenproducing bacteria X9 + B2 was developed by optimizing the combination of strains. The hydrogen-producing ability of X9+ B2 was much greater than that of any single strain. The maximum hydrogen production rate of the complex strain was $12.6 \mathrm{mmol} \mathrm{g}^{-1}$, which was $6.9 \mathrm{mmol} \mathrm{g}^{-1}$ higher than the maximum value of the single strain $\mathrm{X} 9$, which was $5.7 \mathrm{mmol}$ $\mathrm{g}^{-1}$. The maximum biomass of the complex bacteria was $0.88 \mathrm{~g}$ $\mathrm{L}^{-1}$, which was nearly twice that of the single strain X9. The maximum degradation rate of maize straw was $86 \%$ to $80 \%$ higher than that of the single strain X9.

After continuous subculturing for 10, 20, 40, 60, 80, 100 and 120 generations, the combination of strains could maintain the high hydrogen production capacity of the synergistic degradation of maize straw fermentation and showed high functional stability and property stability. There was no significant difference in the hydrogen production rate between generations, with the maximum difference being only $5 \%$.

\section{Methods and materials}

\subsection{Source and cultivation of strains}

Three kinds of pure strains were isolated, screened and purified from molasses wastewater to flow through the hydrogen production reactor (CSTR), namely ethanol-type fermentation hydrogen-producing bacteria (B2, B19, B49), butyric acidfermenting hydrogen-producing bacteria (C3), and butyric acid-degrading cellulose hydrogen-producing bacteria (X9, $\mathrm{X} 12)$.

The preparation and experimental operation of the three kinds of pure strain culture media were carried out by the improved Hungate anaerobic tube technique. ${ }^{17-19}$ High purity nitrogen was the gas phase and conventional culturing was carried out at $35{ }^{\circ} \mathrm{C}$. The liquid medium was composed of glucose $10.0 \mathrm{~mL}$, peptone $4.0 \mathrm{~mL}$, yeast juice $1.0 \mathrm{~mL}, \mathrm{MgCl}_{2} 0.15$ $\mathrm{mL}, \mathrm{FeSO}_{4} 0.15 \mathrm{~mL}, \mathrm{NaCl} 1.0 \mathrm{~mL}, \mathrm{~K}_{2} \mathrm{HPO}_{4} 1.5 \mathrm{~mL}$, beef extract $2.0 \mathrm{~mL}, \mathrm{~L}$-cysteine $0.5 \mathrm{~mL}$, vitamin and trace element liquids 10 $\mathrm{mL}$, resazurin $0.25 \mathrm{~mL}$, distilled water $1000 \mathrm{~mL}$ and medium sterilized at $121{ }^{\circ} \mathrm{C}$ for $20 \mathrm{~min} .^{20,21}$

\subsection{The source and pre-treatment of maize straw}

Maize straw was obtained from a farm in Harbin, Shuangcheng province. Before pre-treatment, the maize straw was cut into $5 \mathrm{~cm}$ segments, then these segments were crushed into 50 mesh powders by a micro-plant pulverizer, and then pre-treated by acidification and steam explosion.

Straw powder $(1.5 \mathrm{~g})$ was weighed and put into a $100 \mathrm{~mL}$ bottle, and $1 \%$ sulphuric acid solution (v/v) was added $(1: 10)$ and mixed. The bottle was sealed and placed in a pressure cooker at $121{ }^{\circ} \mathrm{C}$ for 10 hours. After the steam explosion was completed, the temperature of the autoclave was lowered to $90{ }^{\circ} \mathrm{C}$ and the pressure was decreased. After removal, it was cooled to room temperature. The treated maize straw was washed with water to $\mathrm{pH}=6.5-7.0$ and then dried at $80{ }^{\circ} \mathrm{C}$ to constant weight to obtain the pre-treated maize straw. ${ }^{22-24}$

\subsection{Reactor installation}

The test used a modified Hungate technique in combination with a batch culture test. The device for the intermittent culture test is shown in Fig. 1. ${ }^{25,26}$ First, all the instruments were autoclaved to ensure a sterile environment for the reaction system. Then, high-purity nitrogen (99.9\%) was blown into the culture flask for 10 minutes to evacuate the oxygen therein, and the colour of the anaerobic indicator resazurin $(0.02 \%)$ was used to determine whether the reaction system was in an anaerobic state. The hydrogen-producing bacteria were inoculated into a culture flask containing a culture medium, sealed with a rubber stopper, and then sterilized for use. The culture flask was shaken and cultured in a constant temperature oscillator, and the gas production, $\mathrm{pH}$ value, and hydrogen content were measured periodically. When reading the amount of gas produced, the balance liquid level was equal to the liquid level of the gas meter to ensure the accuracy of the measured value.

\subsection{Intermittent experiment}

Three kinds of pure strains, namely ethanol-type fermenting hydrogen-producing bacteria (B2, B19, B49), butyric acidfermenting hydrogen-producing bacteria (C3) and butyric

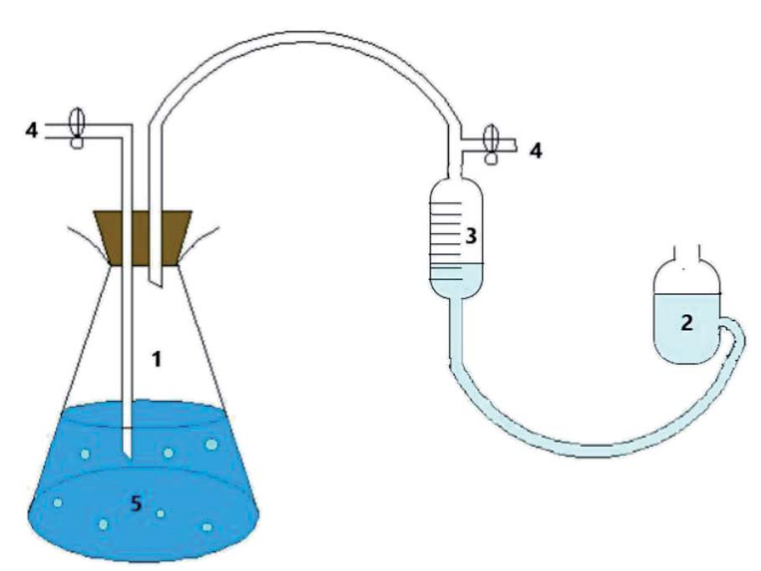

Fig. 1 Batch culture test reactor: (1), culture bottle; (2), balance bottle; (3), gas meter; (4), sample outlet; (5), culture medium. 
acid-degrading cellulose hydrogen-producing bacteria (X9, X12) were used to construct a high-efficiency hydrogen-producing complex bacterial community for the simultaneous fermentation of maize straw.

Through batch culture experiments, the effects of substrate concentration, $\mathrm{pH}$, culture time and L-cysteine on the simultaneous and efficient hydrogen production of $\mathrm{X} 9$ and $\mathrm{B} 2$ were investigated, and the optimal conditions for hydrogen production by complex bacteria were selected.

The hydrogen production kinetics of the complex bacteria was analysed by measuring the hydrogen production rate, biomass, degradation rate and $\mathrm{pH}$. After continuous subculturing and culturing of the $10^{\text {th }}, 20^{\text {th }}, 40^{\text {th }}, 60^{\text {th }}, 80^{\text {th }}, 100^{\text {th }}$ and $120^{\text {th }}$ generations, the hydrogen production stability of the complex bacteria was analysed.

The hydrogen production capacity is expressed based on the hydrogen production rate $\left(\mathrm{mmol} \mathrm{g}^{-1}\right)$, and the calculation is as follows:

$$
Y_{\mathrm{H}_{2} / \mathrm{S}}=\frac{\text { Accumulative hydrogen molar amount }}{\text { Substrate utilization quality }}
$$

The degradation rate of maize straw was determined by the weight reduction method. The maize straw was accurately weighed before and after fermentation, and the quality loss was the amount of maize straw degraded by bacteria to produce hydrogen. The degradation rate of maize straw was characterized by the difference between the quality of maize straw before and after fermentation.

The volatile acids and alcohols in fermentation liquid end products were analysed by GC122 gas chromatography.

Hydrogen was determined by SCII gas chromatography.

\section{Results and discussion}

\subsection{Optimization of hydrogen-producing complex bacteria in degraded maize straw}

3.1.1 Determination of the composition of the bacteria. Three kinds of pure strains were selected, namely ethanol-type fermentation hydrogen-producing bacteria (B2, B19, B49), butyric acid-fermenting hydrogen-producing bacteria (C3) and butyric acid-degrading cellulose hydrogen-producing bacteria (X9, X12) for hydrogen production testing. The test used the hydrogen production rate of each compounding scheme to measure and determine the best combination scheme for the production of hydrogen by complex bacteria to degrade maize straw. The specific compounding scheme and hydrogen production capacity are shown in Table 1.

The results of the compound combination test showed that when X9 and B2 were mixed, maize straw (15 $\left.\mathrm{g} \mathrm{L}^{-1} 100 \mathrm{~mL}\right)$ that was pre-treated with acidified steam explosion showed high hydrogen production ability, and the hydrogen production rate was up to $12.2 \mathrm{mmol} \mathrm{g}^{-1}$. This indicates that the combination of $\mathrm{X} 9$ and $\mathrm{B} 2$ was the best compounding scheme for degrading the hydrogen-producing complex of maize straw.

3.1.2 Optimization of the bacterial group compounding scheme. By changing the inoculation ratio of the strains, the
Table 1 Experiment on the interaction of complex bacteria

\begin{tabular}{lc}
\hline Compounding scheme & $\begin{array}{c}\text { Hydrogen production } \\
\text { rate }\left(\mathrm{mmol} \mathrm{g}^{-1}\right)\end{array}$ \\
\hline X9 & 6.1 \\
X12 & 5.3 \\
X9 + X12 & 5.2 \\
X9 + C3 & 4.6 \\
X9 + B2 & 12.2 \\
X9 + B19 & 11.4 \\
X9 + B49 & 11.7 \\
X12 + C3 & 4.0 \\
X12 + B2 & 10.1 \\
X12 + B19 & 9.5 \\
X12 + B49 & 9.9
\end{tabular}

content of enzymes of different components can be adjusted and the ability of maize straw to degrade hydrogen production can be improved as a whole.

In this experiment, maize straw $\left(15 \mathrm{~g} \mathrm{~L}^{-1}, 100 \mathrm{~mL}\right)$ was used as the substrate for fermenting hydrogen production, and the hydrogen production rate was taken as the index to investigate the effects of inoculation amount and proportion of X9+ B2 on its growth and hydrogen production capacity. Thus, the optimal inoculation amount and inoculation proportion of the composite bacteria were determined (Table 2).

The results showed that when the inoculation amount of the complex bacteria was $6 \mathrm{~mL}(6 \%)$ and the inoculation ratio was $1: 1$, the hydrogen production rate could reach $12.6 \mathrm{mmol} \mathrm{g}^{-1}$. Compared with the inoculation amount of $8 \mathrm{~mL}(8 \%)$ and the inoculation ratio of $1: 1$, although the inoculum amount was reduced by $25 \%$, the hydrogen production rate at this time was only decreased by $0.8 \%$. When the inoculation amount was less than $6 \%$, the growth of the strain was slow, the culture time was long, and the enzyme production activity and hydrogen

Table 2 Experiment on the optimized compounds of complex bacteria

\begin{tabular}{llll}
\hline & \multicolumn{2}{l}{$\begin{array}{l}\text { Strain } \\
\text { inoculum }(\mathrm{mL})\end{array}$} & \\
\cline { 2 - 3 } Order number & X9 & B2 & $\begin{array}{l}\text { Hydrogen production } \\
\text { rate }\left(\mathrm{mmol} \mathrm{g}^{-1}\right)\end{array}$ \\
\hline 1 & 1 & 1 & 4.2 \\
2 & 1 & 2 & 5.2 \\
3 & 1 & 3 & 5.6 \\
4 & 1 & 4 & 5.7 \\
5 & 2 & 1 & 7.6 \\
6 & 2 & 2 & 8.2 \\
7 & 2 & 3 & 9.1 \\
8 & 2 & 4 & 9.1 \\
9 & 3 & 1 & 10.1 \\
10 & 3 & 2 & 11.2 \\
11 & 3 & 3 & 12.5 \\
12 & 3 & 4 & 12.6 \\
13 & 4 & 1 & 10.7 \\
14 & 4 & 2 & 11.4 \\
15 & 4 & 3 & 12.6 \\
16 & 4 & 4 & 12.7
\end{tabular}


production ability were not high. When the inoculation amount exceeded $6 \%$, the inoculation amount did not significantly increase the hydrogen production capacity, so the enzyme activity, biomass and hydrogen production rate cannot be simply increased by increasing the inoculum amount.

In addition, considering the cost of industrial application, when the inoculum of the strains X9 and B2 was $6 \mathrm{~mL}(6 \%)$ and the inoculation ratio was also $1: 1$, the hydrogen production effect was achieved. In different compounding schemes, the hydrogen production capacity increased significantly with the increase of the inoculum of strain X9 in the complex bacteria, indicating that strain X9 was the "dominant strain". However, the hydrogen production ability of strain B2 was not obvious with the increase in the inoculation amount in the complex bacteria group, which indicated that strain B2 was an "auxiliary strain". At the same time, the complex bacteria mainly utilized the synergistic effect of cellulose enzymatic saccharification and enzymatic hydrolysis of the saccharification solution to produce hydrogen to achieve the high-efficiency degradation of maize straw fermentation for hydrogen production. ${ }^{27}$ In this sense, the strains X9 and B2 in the complex bacteria were "equally important". The results also showed that when the inoculation ratio of the complex bacteria was $1: 1$, higher hydrogen production capacity could be obtained.

\subsection{Influence of a single factor on the ability of complex bacteria}

3.2.1 Effect of initial $\mathrm{pH}$ on hydrogen production by complex bacteria. The experiment investigated the effect of the initial $\mathrm{pH}$ value on the hydrogen production capacity of the complex bacteria to degrade maize straw. The initial $\mathrm{pH}$ values were $3.0,3.5,4.0,4.5,5.0,5.5,6.0,6.5,7.0$ and 7.5.

The results in Fig. 2 show that when the initial $\mathrm{pH}$ value was 6.5 , the hydrogen production rate and biomass of strain X9 reached their respective maximum values of $5 \mathrm{mmol} \mathrm{g}^{-1}$ and $0.51 \mathrm{~g} \mathrm{~L}^{-1}$, respectively. For the single strain $\mathrm{B} 2$, the initial $\mathrm{pH}$ change had no effect on its hydrogen production rate and biomass. For the complex bacteria, the initial $\mathrm{pH}$ ranged from 3.0 to 6.0 . With the initial $\mathrm{pH}$ increase, the hydrogen production rate and biomass of the complex strain were $90 \%$ and $27.5 \%$ higher than the maximum value of the single strain $\mathrm{X} 9$, respectively. It can be seen from the above figure that the initial $\mathrm{pH}$ range of the complex bacteria is much wider than that of the single strain X9. It also indicates that the complex bacteria played a synergistic role and had high efficiency in the processes of degrading maize straw by fermentation and hydrogen production.

The synergistic degradation of maize straw to produce hydrogen by fermentation with complex bacteria was best at the initial $\mathrm{pH}$ between 5.5 and 6.0. The ability of maize straw to degrade, saccharify and ferment hydrogen production was greatly improved. At an initial $\mathrm{pH}$ of 6.0, the degradation rate of maize straw reached a maximum of $80 \%$, which was nearly $60 \%$ higher than the maximum value of single strain X9.

From the initial $\mathrm{pH}$ of the medium to the final $\mathrm{pH}$ effect curve of the fermentation hydrogen production reaction system,
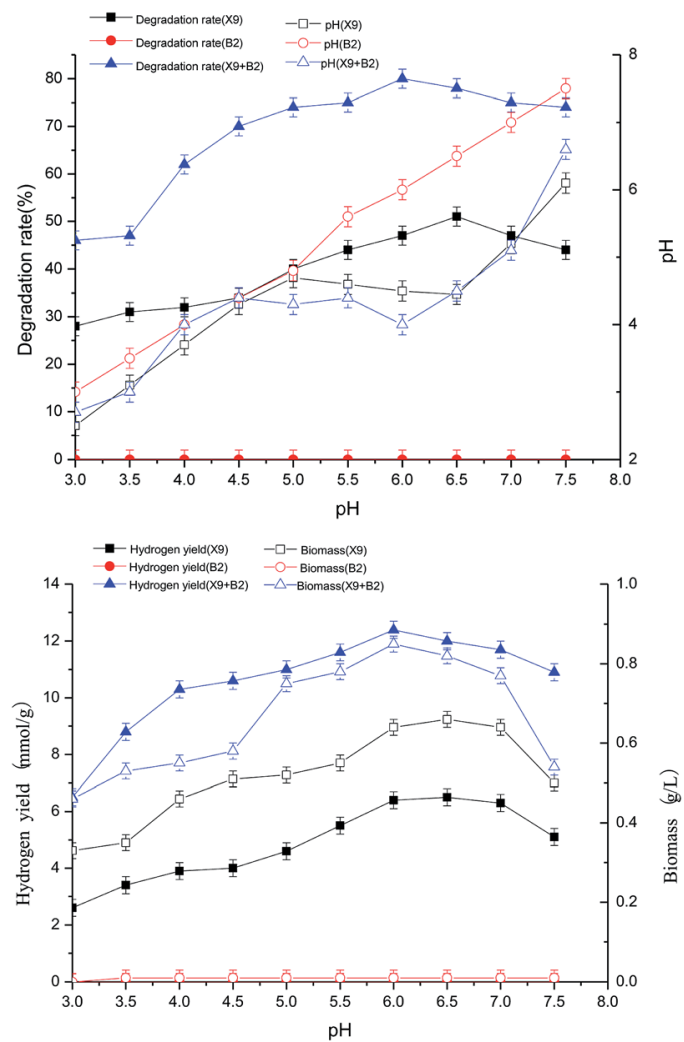

Fig. 2 Effects of $\mathrm{pH}$ on cell growth and $\mathrm{H}_{2}$ production of $\mathrm{X} 9, \mathrm{~B} 2$ and complex bacteria.

it can be seen that the complex bacteria can adapt to a wider $\mathrm{pH}$ range, showing the advantage of using complex bacteria in the synergistic degradation of maize straw for hydrogen production.

3.2.2 The effect of substrate concentration on hydrogen production capacity by complex bacteria. The maize straw after acidification and steam explosion was selected as the nutrient substrate for hydrogen production by fermentation, and the substrate concentration was set to $1.0,3.0,6.0,9.0,12.0,15.0$, 18.0 and $21.0 \mathrm{~g} \mathrm{~L}^{-1}$, respectively.

The results of the above figures show that the single strain X9 had a maximum hydrogen production rate and biomass of $5.0 \mathrm{mmol} \mathrm{g}^{-1}$ and $0.4 \mathrm{~g} \mathrm{~L}^{-1}$, respectively, at a substrate concentration of $9.0 \mathrm{~g} \mathrm{~L}^{-1}$. However, the change in substrate concentration of single strain B2 had no effect on its hydrogen production rate and biomass. For the complex bacteria, the substrate concentration was between 1.0 and $12.0 \mathrm{~g} \mathrm{~L}^{-1}$. With the gradually increasing substrate concentration, the hydrogen production rate of the complex bacteria and the degradation rate of the maize straw were greatly improved. When the substrate concentration was $12.0 \mathrm{~g} \mathrm{~L}^{-1}$, the complex bacteria group synergistically degraded the maize straw to produce better hydrogen, which was $100 \%$ and $59 \%$ higher than the maximum value of single strain X9. When the substrate concentration was between 12.0 and $21.0 \mathrm{~g} \mathrm{~L}^{-1}$, the hydrogen production rate and biomass showed a decreasing trend with the further increase of substrate concentration. 
For the complex bacteria, as the substrate concentration increased, the degradation rate of maize straw increased. When the substrate concentration was $12 \mathrm{~g} \mathrm{~L} \mathrm{~L}^{-1}$, along with the increase in the hydrogen production rate, the degradation rate of maize straw reached $83 \%$ at the maximum, which was $66 \%$ higher than the maximum value of single strain X9. This indicates that the synergistic degradation of the complex bacteria to produce hydrogen from maize straw fermentation had great advantages in both the loading rate of the fermentation substrate and the degradation rate of the substrate and the high efficiency of hydrogen production by fermentation.

The results show that the process of hydrogen production by fermenting maize straw was inhibited by the complex bacteria. When the substrate concentration was $12.0 \mathrm{~g} \mathrm{~L}^{-1}$, it was the best substrate load for the degradation of hydrogen by maize straw fermentation (Fig. 3).

3.2.3 The effect of culture time on the hydrogen production capacity of complex bacteria. The mid to late period of the bio-logarithmic growth phase of the microbial experiment was selected to control the culture time to $26,28,30,32,34,36,38$, 40,42 and $44 \mathrm{~h}$ in the middle and late stages of hydrogen production by fermentation. The results are shown in Fig. 4.

When the single strain X9 was cultured for $36 \mathrm{~h}$, the hydrogen production rate and biomass reached their maximum values, which were $4.8 \mathrm{mmol} \mathrm{g}^{-1}$ and $0.42 \mathrm{~g} \mathrm{~L}^{-1}$, respectively. However, the change in culture time of single strain B2 had no

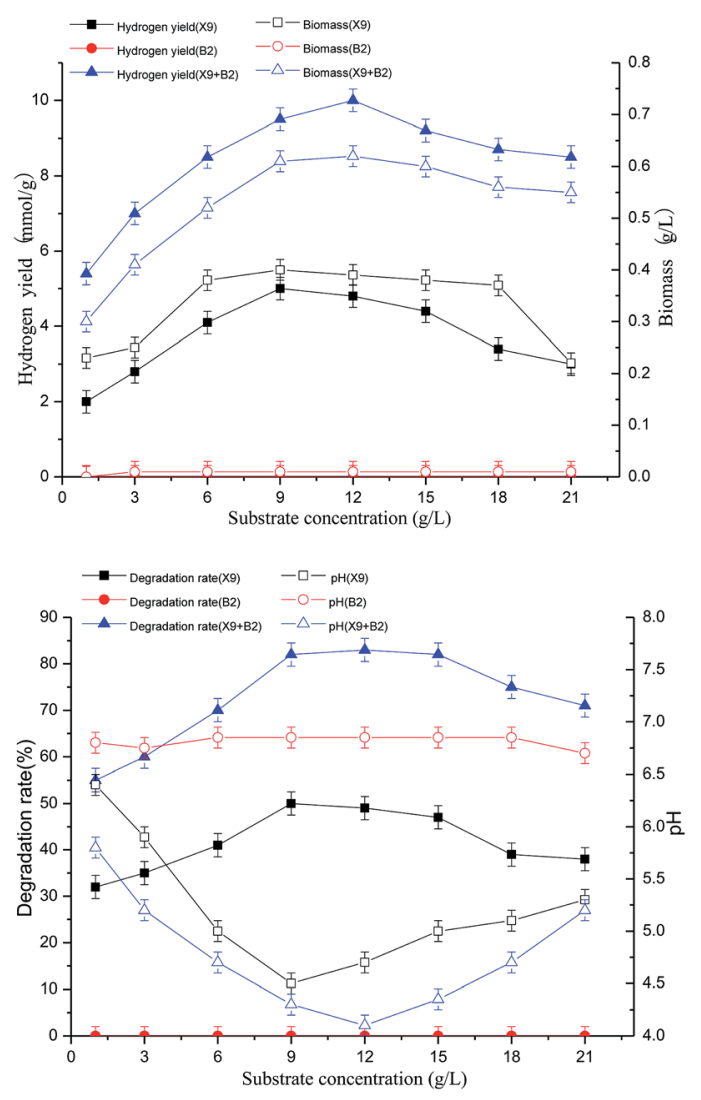

Fig. 3 Effects of substrate concentration on cell growth and $\mathrm{H}_{2}$ production of X9, B2 and complex bacteria.
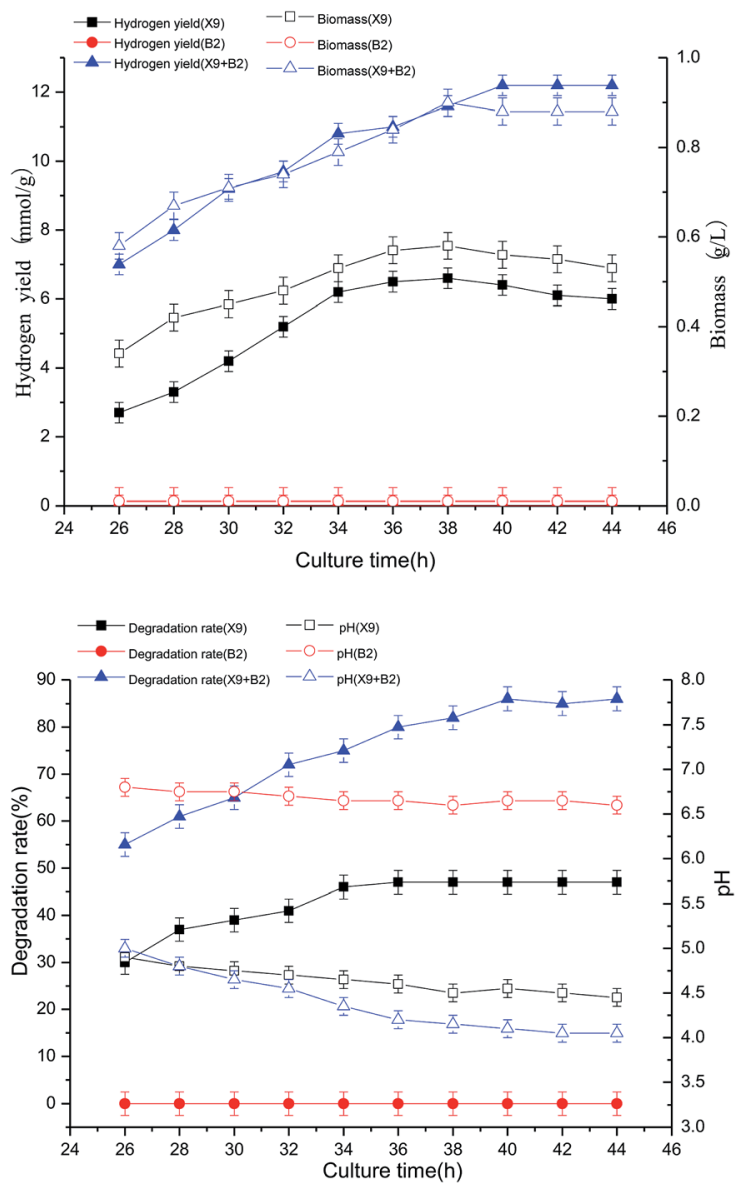

Fig. 4 Effects of culture time on cell growth and $\mathrm{H}_{2}$ production of X9, B2 and complex bacteria.

effect on the hydrogen production rate and biomass. When the culture time reached $40 \mathrm{~h}$, the hydrogen production rate and biomass reached their respective maximum values, which were $104 \%$ and $64 \%$ higher than the maximum value of the single strain X9, respectively. It can be seen from Fig. 4 that the optimal culture time of the complex bacteria was delayed by 4-6 hours as compared to the optimal culture time of the single strain X9. This indicates that the prolongation of hydrogen production by the complex bacteria improves the effectiveness of the degradation and utilization of maize straw, and is more conducive to the full play of the complex bacteria on the enzymatic saccharification and fermentative production of maize straw. It was also manifested that the complex bacteria were more effective than the single strain in utilizing the superiority of maize straw fermentation to produce hydrogen.

The best culture time for single strain X9 was $36 \mathrm{~h}$, and the maximum maize straw degradation rate was $47 \%$, then it gradually stabilized. B2 did not change the utilization of maize straw. For the complex bacteria, when the culture time was between 26 and $40 \mathrm{~h}$, the degradation ability of maize straw was greatly improved by the increase of fermentation time. At $40 \mathrm{~h}$ of culture time, the degradation rate of maize straw reached a maximum of $86 \%$. It was $45 \%$ higher than the maximum value of the single strain X9. 
Therefore, determining a suitable culture time can not only fully exert the synergistic effect of the complex microbial community on the fermentation of maize straw to produce hydrogen, improving the utilization of maize straw and the ability to ferment hydrogen production, but can also effectively optimize the fermentation reaction time to provide operating parameters for the actual application.

\subsection{Optimization of the hydrogen production capacity of complex bacteria by the response surface methodology}

3.3.1 Box-Behnken design and results. Based on the results of the single factor test, according to the design principle of the Box-Behnken test, 17 sets of test points were designed, including 12 sets of factor points and 5 sets of zero points to estimate the error. The test design and results are shown in Table 3 .

3.3.2 Establishment of a quadratic regression model and analysis of variance. The Design Expert program was used to perform regression calculation on 17 test points, and a quadratic response surface regression model was established, as shown in eqn (1); the regression equation was analyzed by the variance and coefficient significance tests. The results are shown in Table 4 and 5.

$$
\begin{aligned}
Y= & -160.438+1.35225 \times A+22.843 \times B+4.79 C \\
& -0.1725 \times \mathrm{AB}+4.375 \times 10^{-3} \times \mathrm{AC}-0.0175 \times \mathrm{BC} \\
& -0.021188 \times A^{2}-1.799 \times B^{2}-0.061187 \times C^{2}
\end{aligned}
$$

The regression coefficient of the above-mentioned quadratic regression full model equation is $R^{2}=0.9890$. It can be seen from the variance analysis results of the regression model of Table 4 that the established model can reflect the experimental data well, and the regression equation has a good fitting degree and small experimental error. At the significance level of $p<$ 0.05 , based on the analysis of the regression equation, the initial $\mathrm{pH}$ and culture time of the primary hydrogen production regression model were high, the secondary items $A^{2}, B^{2}$, and $C^{2}$ all showed significant results and the interaction item is only $\mathrm{AB}$ significant.

In the coefficient test of the regression equation, the $95 \%$ confidence interval (CI) indicates that the coefficient average is more reliable; the variance expansion coefficient (VIF) is much smaller than the general requirement of 10, indicating that the collinearity between the regression coefficients is small. The missing term of the model is $p=0.0548>0.05$, indicating that the loss is not significant, that is, the model is stable, which can better predict the change in the hydrogen production rate of the actual complex bacteria degradation of maize straw. Therefore, this model can be used to analyze and predict the hydrogen production rate.

3.3.3 Response surface analysis of hydrogen production. Based on the quadratic regression model, the response surface $3 \mathrm{D}$ and contour plots with significant various factor are given in Fig. 5.

It can be seen from Fig. 5A that the substrate concentration and the initial $\mathrm{pH}$ had significant effects on hydrogen production by the degradation of maize straw by complex bacteria. When the substrate concentration was raised from $10 \mathrm{~g} \mathrm{~L}^{-1}$ to $12 \mathrm{~g} \mathrm{~L}^{-1}$ and the initial $\mathrm{pH}$ was increased from 5.5 to 6.0 , the hydrogen production rate increased sharply. However, on further increasing the substrate concentration and initial $\mathrm{pH}$, the hydrogen production rate decreased.

The effect of culture time on the hydrogen production of the complex bacteria to degrade maize straw can be seen from Fig. 5B. When the substrate concentration and culture time were increased from $10 \mathrm{~g} \mathrm{~L}^{-1}$ and $38 \mathrm{~h}$ to $12 \mathrm{~g} \mathrm{~L}^{-1}$ and $40 \mathrm{~h}$,

\begin{tabular}{|c|c|c|c|c|c|c|c|}
\hline \multirow[b]{2}{*}{ Run } & \multicolumn{2}{|c|}{$\begin{array}{l}\text { Substrate } \\
\text { concentration }\left(\mathrm{g} \mathrm{L}^{-1}\right)\end{array}$} & \multicolumn{2}{|l|}{$\mathrm{pH}$} & \multicolumn{2}{|c|}{ Culture time $(\mathrm{h})$} & \multirow{2}{*}{$\begin{array}{l}\text { Hydrogen yield } \\
\left(\mathrm{mmol} \mathrm{g}^{-1}\right)\end{array}$} \\
\hline & A & Code A & B & Code B & $\mathrm{C}$ & Code C & \\
\hline 1 & 12 & 0 & 6 & 0 & 40 & 0 & 12.6 \\
\hline 2 & 14 & 1 & 5.5 & -1 & 40 & 0 & 12 \\
\hline 3 & 12 & 0 & 6 & 0 & 40 & 0 & 12.6 \\
\hline 6 & 14 & 1 & 6 & 0 & 42 & 1 & 12.4 \\
\hline 7 & 10 & -1 & 6 & 0 & 42 & 1 & 12.3 \\
\hline 8 & 12 & 0 & 5.5 & -1 & 42 & 1 & 12.1 \\
\hline 9 & 12 & 0 & 6.5 & 1 & 42 & 1 & 12 \\
\hline 10 & 12 & 0 & 6 & 0 & 40 & 0 & 12.6 \\
\hline 11 & 14 & 1 & 6.5 & 1 & 40 & 0 & 11.8 \\
\hline 16 & 14 & 1 & 6 & 0 & 38 & -1 & 12.3 \\
\hline 17 & 10 & -1 & 6 & 0 & 38 & -1 & 12.2 \\
\hline
\end{tabular}
respectively, the hydrogen production rate reached the

Table 3 Experimental design and results of the Box-Behnken test 
Table 4 ANOVA for the response surface quadratic model

\begin{tabular}{|c|c|c|c|c|c|c|}
\hline Source & Sum of squares & Df & Mean square & $F$ Value & Prob $>F$ & \\
\hline Model & 1.46 & 9 & 0.16 & 49.26 & $<0.0001$ & Significant \\
\hline A-substrate concentration & $8.450 \times 10^{-3}$ & 1 & $8.450 \times 10^{-3}$ & 2.56 & 0.1538 & \\
\hline C-culture time & 0.088 & 1 & 0.088 & 26.69 & 0.0013 & \\
\hline $\mathrm{AB}$ & 0.12 & 1 & 0.12 & 36.02 & 0.0005 & \\
\hline $\mathrm{AC}$ & $1.225 \times 10^{-3}$ & 1 & $1.225 \times 10^{-3}$ & 0.37 & 0.5618 & \\
\hline$B^{2}$ & 0.85 & 1 & 0.85 & 257.75 & $<0.0001$ & \\
\hline$C^{2}$ & 0.25 & 1 & 0.25 & 76.33 & $<0.0001$ & \\
\hline Residual & 0.023 & 7 & $3.304 \times 10^{-3}$ & & & \\
\hline Lack of fit & 0.019 & 3 & $6.350 \times 10^{-3}$ & 6.23 & 0.0548 & Not significant \\
\hline Pure error & $4080 \times 10^{-3}$ & 4 & $1.020 \times 10^{-3}$ & & & \\
\hline Cor total & 1.49 & 16 & & & & \\
\hline
\end{tabular}

maximum value. After the substrate concentration and culture time continued to increase, the hydrogen production decreased.

It can be seen from Fig. 5C that as the initial $\mathrm{pH}$ and the incubation time increased to the optimum value of initial $\mathrm{pH}$ 6.0 and the incubation time was $40 \mathrm{~h}$, the hydrogen production amount gradually increased to the highest value of $12.6 \mathrm{mmol}$ $\mathrm{g}^{-1}$. The initial $\mathrm{pH}$ and incubation time continued to increase, and the amount of hydrogen produced showed a decreasing trend.

3.3.4 Determination and verification of optimal process. Based on the above response surface analysis, the maximum hydrogen yield was $12.626 \mathrm{mmol} \mathrm{g}^{-1}$ when the substrate concentration was $11.73 \mathrm{~g} \mathrm{~L}^{-1}$, the initial $\mathrm{pH}$ was 5.98 and the culture time was $40.42 \mathrm{~h}$. Based on the industrial production situation, the optimal solution is a substrate concentration of $12 \mathrm{~g} \mathrm{~L}^{-1}, \mathrm{pH}$ of 6 and incubation time of $40 \mathrm{~h}$, when the hydrogen yield rate was $12.612 \mathrm{mmol} \mathrm{g}^{-1}$. In order to verify the accuracy of the model prediction, three repeated hydrogen production tests were carried out according to the substrate concentration of $11.73 \mathrm{~g} \mathrm{~L}^{-1}$, the initial $\mathrm{pH}$ of 5.98 and the incubation time of $40.42 \mathrm{~h}$. The experimental results were 12.60, 12.56 and $12.62 \mathrm{mmol} \mathrm{g}^{-1}$, the average value was $12.59 \mathrm{mmol}$ $\mathrm{g}^{-1}$, and the hydrogen production reached $99.8 \%$ of the theoretical value. The experimental values were basically consistent with the model optimization simulation values, and a higher hydrogen production amount was obtained, which indicated that the optimized model was reliable.

\subsection{Synergistic hydrogen production by degradation of maize straw}

3.4.1 Study on the synergistic hydrogen production ability of complex bacteria by degradation of maize straw. In this paper, we analyzed the hydrogen production capacity of the codegradation of maize straw by complex microbial bacteria based on hydrogen production rate, biomass, degradation rate and $\mathrm{pH}$.

It can be seen from Fig. 6 that both single strain X9 and the complex bacteria can ferment maize straw and produce hydrogen, and the hydrogen production rate, maize straw degradation rate and biomass change all have similar trends with the fermentation hydrogen production time. However, the hydrogen production capacity of the complex bacteria was significantly higher than that of the single strain $\mathrm{X} 9$, and the maximum hydrogen production rate of the complex bacteria was $12.6 \mathrm{mmol} \mathrm{g}^{-1}$, which was $6.9 \mathrm{mmol} \mathrm{g}^{-1}$ higher than the

Table 5 Test of significance of the regression coefficient

\begin{tabular}{|c|c|c|c|c|c|c|}
\hline \multirow[b]{2}{*}{ Factor } & \multirow{2}{*}{$\begin{array}{l}\text { Coefficient } \\
\text { estimate }\end{array}$} & \multirow[b]{2}{*}{ Df } & \multirow[b]{2}{*}{ Standard error } & \multicolumn{2}{|l|}{$\underline{95 \% \mathrm{CI}}$} & \multirow[b]{2}{*}{ VIF } \\
\hline & & & & Low & High & \\
\hline Intercept & 12.61 & 1 & 0.026 & 12.55 & 12.67 & 1.00 \\
\hline A-substrate concentration & -0.032 & 1 & 0.020 & -0.081 & 0.016 & 1.00 \\
\hline B-pH & -0.058 & 1 & 0.020 & -0.11 & $-9.443 \times 10^{-3}$ & 1.00 \\
\hline C-culture time & 0.11 & 1 & 0.020 & 0.057 & 0.15 & 1.00 \\
\hline $\mathrm{AB}$ & -0.17 & 1 & 0.029 & -0.24 & -0.10 & 1.00 \\
\hline $\mathrm{AC}$ & 0.018 & 1 & 0.029 & -0.050 & 0.085 & 1.00 \\
\hline $\mathrm{BC}$ & 0.018 & 1 & 0.029 & -0.050 & 0.085 & 1.00 \\
\hline$A^{2}$ & -0.085 & 1 & 0.028 & -0.15 & -0.019 & 1.01 \\
\hline$B^{2}$ & -0.45 & 1 & 0.028 & -0.52 & -0.38 & 1.01 \\
\hline$C^{2}$ & -0.24 & 1 & 0.028 & -0.31 & -0.18 & 1.01 \\
\hline
\end{tabular}



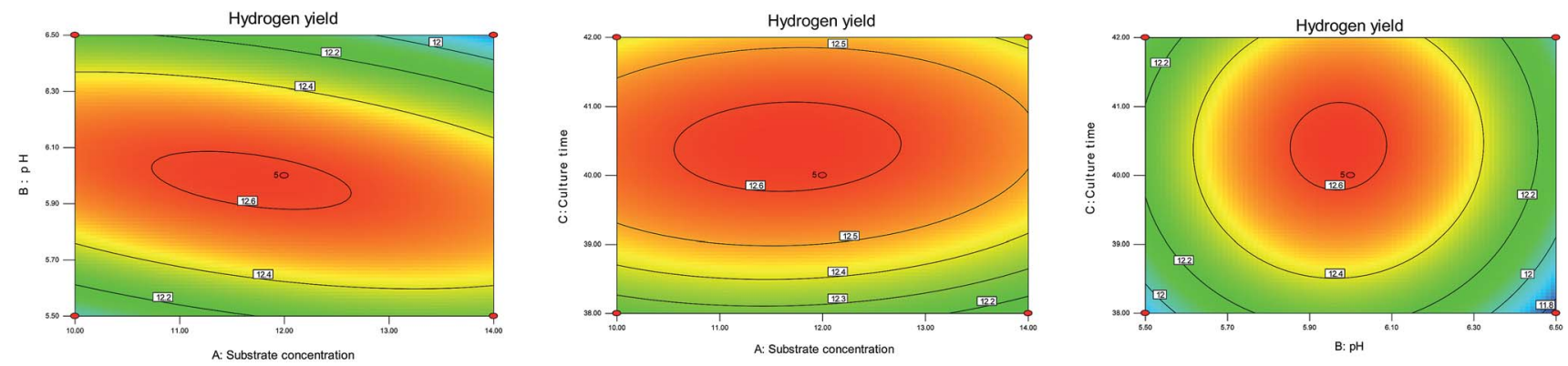

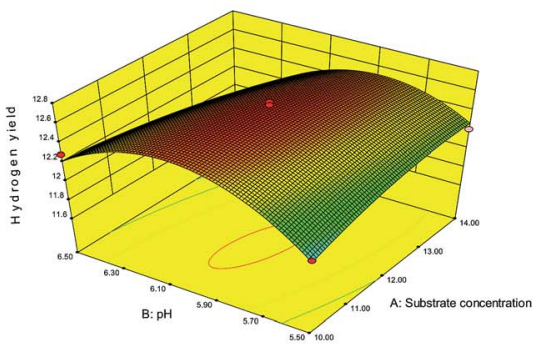

A

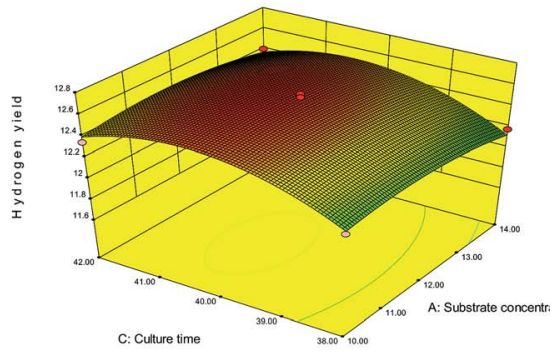

B

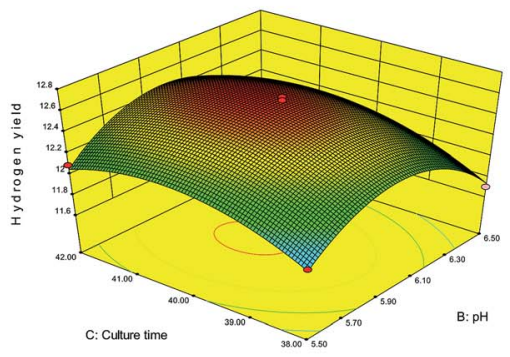

C

Fig. 5 Trend plots of different factors by the response surface methodology. (A). Effect of substrate concentration and culture time on hydrogen production rate. (B). Effect of substrate concentration and culture time on hydrogen production rate. (C). Effect of initial pH and incubation time on hydrogen production rate.
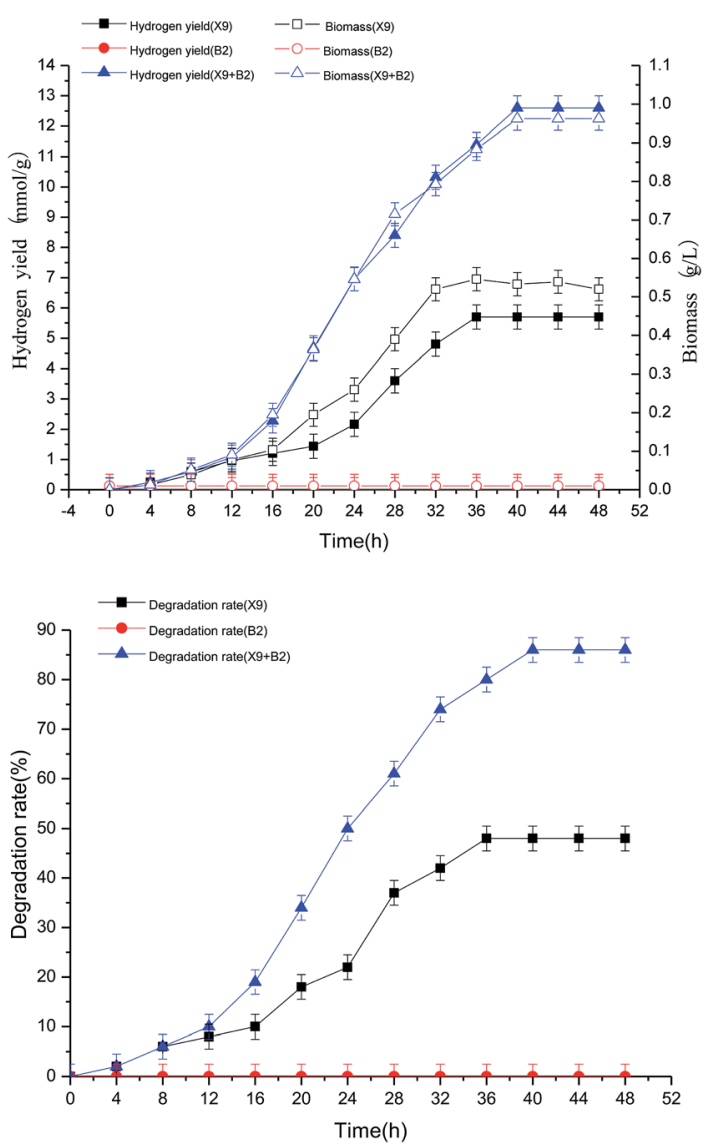

Fig. 6 Time course of the $\mathrm{H}_{2}$ production capability of complex bacteria in the batch test. maximum value of the single strain $\mathrm{X9}$. At this time, the maximum biomass of the complex bacteria reached $0.88 \mathrm{~g} \mathrm{~L}^{-1}$, which was nearly twice that of the single strain $\mathrm{x} 9$, and the maximum $86 \%$ of the maize straw degradation rate was also increased by nearly $80 \%$, corresponding to the maximum value of the single strain X9. These explanations showed that the synergistic hydrogen production of the complex bacteria was significantly superior to the single strain when fermenting maize straw to produce hydrogen. Because strain B2 cannot directly ferment the maize straw to produce hydrogen, there was basically no change in the indicators in the figure. The fermentation hydrogen production time $(40 \mathrm{~h})$ for the complex bacteria was 5 hours longer than that of the single strain X9 (35 $\mathrm{h}$ ), which was beneficial to increase the degree of degradation of maize straw and promote hydrogen production.

3.4.2 Hydrogenase mechanism of the synergistic fermentation of complex bacteria. Hydrogen production by the synergistic degradation of maize straw by complex bacteria mainly involves the enzymatic saccharification of the maize straw pretreated by the acidification and steam explosion under the action of the cellulose degrading enzyme, which degrades the cellulose hydrogen production enzyme. Under the combined action of the complex bacteria, the glucose produced by the enzymatic hydrolysis of maize straw is used to produce hydrogen. Therefore, in the process of decomposing maize straw by complex bacteria, strains X9 and B2 promote enzyme production and enzyme activity and use a synergistic metabolism to relieve the inhibition of enzymes in time to achieve the desired effect of degrading cellulose to produce hydrogen.

Cellulases include endoglucanases, exoglucanases, and betaglucosidases. ${ }^{28}$ Based on existing research and related data, it is 
hypothesized that endoglucanase and exoglucanase act simultaneously on insoluble cellulose, which is random in sequence. After the glucanase degrades the maize straw to produce cellobiose, the cellobiose is further hydrolyzed into 2 molecules of glucose by 20 -glucosidase. ${ }^{29-32}$ Hydrogen is then produced by the action of related hydrogenase, NADH-iron oxidoreductase and dehydrogenase. Current studies have shown that cellobiose, the main product of cellulase hydrolysis of cellulose, has a significant inhibitory effect on the activity of endoglucanase and exo-cellobiohydrolase. The main rate-limiting step in the hydrolysis of cellulose by cellulase is the hydrolysis of cellobiose to glucose..$^{33,34}$

The synergistic metabolism of B2 in the complex bacteria utilizes some cellobiose as a nutrient substrate for hydrogen production, which reduces the content of cellobiose in the system to some extent, and alleviates the feedback inhibition of cellulolytic enzymes by cellobiose. In this way, on the one hand, the further enzymatic saccharification of cellulose is promoted; on the other hand, the ability of the fermentation period is also improved, which is advantageous for obtaining a higher hydrogen yield. In addition, enhancing $\beta$-glucosidase activity is another effective measure to increase the rate of cellulase hydrolysis and hydrogen production.

Furthermore, studies have shown that the accumulation of glucose inhibits the activity of $\beta$-glucosidase and acts as a repressor in cellulase synthesis, which in turn leads to the accumulation of cellobiose and more glucose. At the same time, it will inhibit other cellulases and cause a vicious cycle.

In addition, some studies have shown that the accumulation of glucose inhibits the activity of $\beta$-glucosidase and acts as a repressor in cellulase synthesis, ${ }^{35}$ which in turn leads to the accumulation of cellobiose and more glucose. At the same time, it will inhibit other cellulases and cause a vicious cycle. The repression of glucose by cellulase is produced by the regulation of a repressor protein interacting with a specific nucleotide motif sequence upstream of the target gene promoter. The complex bacteria that we use to synergistically degrade the fermentation of cellulose to produce hydrogen are based on this starting point. B2 in the complex bacteria can fully degrade the glucose produced by $\mathrm{X} 9$ enzymatic hydrolysis to produce hydrogen, which can effectively relieve the feedback inhibition of the enzyme by the glucose product and improve the hydrogen production capacity of the complex bacteria.

\subsection{Analysis of the hydrogen production stability of complex bacteria}

For any microorganism degrading maize straw to produce hydrogen, the ability to degrade maize straw to consistently produce hydrogen is the most basic prerequisite for its application. After long-term testing and continuous subculturing of the complex bacteria, it was found that the ability to degrade maize straw for the production of hydrogen always maintained good functional stability.

In this experiment, the complex bacteria of the $10^{\text {th }}, 20^{\text {th }}$, $40^{\text {th }}, 60^{\text {th }}, 80^{\text {th }}, 100^{\text {th }}$ and $120^{\text {th }}$ generations of continuous subculture and cryopreservation were activated as the seed and cultured under optimal culture conditions for 48 hours. Through intermittent testing, the hydrogen production rate, biomass, maize straw degradation rate and $\mathrm{pH}$ were used to investigate the functional stability and stability of the complex bacteria, which provided the basis for the experimental biohydrogen production using maize straw.

After successive subculturing and the $10^{\text {th }}, 20^{\text {th }}, 40^{\text {th }}, 60^{\text {th }}$, $80^{\text {th }}, 100^{\text {th }}$ and $120^{\text {th }}$ generations, the biological activities of the complex bacteria of each generation were kept at a high level, the cell proliferation was rapid, the metabolic enzyme production was strong, and the enzyme activity was high. The hydrogen production rate and biomass change trend were stable, there was no significant difference between generations, and both had high bio-capacity while maintaining high hydrogen production rates (see figure below). The maximum hydrogen production rate and biomass were basically stable at the levels of $13.26 \mathrm{mmol} \mathrm{g}^{-1}$ and $0.97 \mathrm{~g} \mathrm{~L}^{-1}$. This indicates that the complex bacteria of each generation maintained a high ability to degrade the fermentation of maize straw to produce hydrogen, and had good functional stability (Fig. 7).

It can be seen from Fig. 8 that the degradation rate of maize straw by different generations of complex bacteria was the same as that for hydrogen production and biomass. There was no significant difference between the generations, with the greatest difference being only $5 \%$, and both of them maintained a high maize straw degradation rate, with the maximum maize straw degradation rate being basically stable at about $85 \%$. This reflected the relatively stable nature of the complex bacteria, which also showed stability between different generations. The stability of the function and properties of the single strain largely determined the stability of hydrogen production and efficiency of hydrogen production.

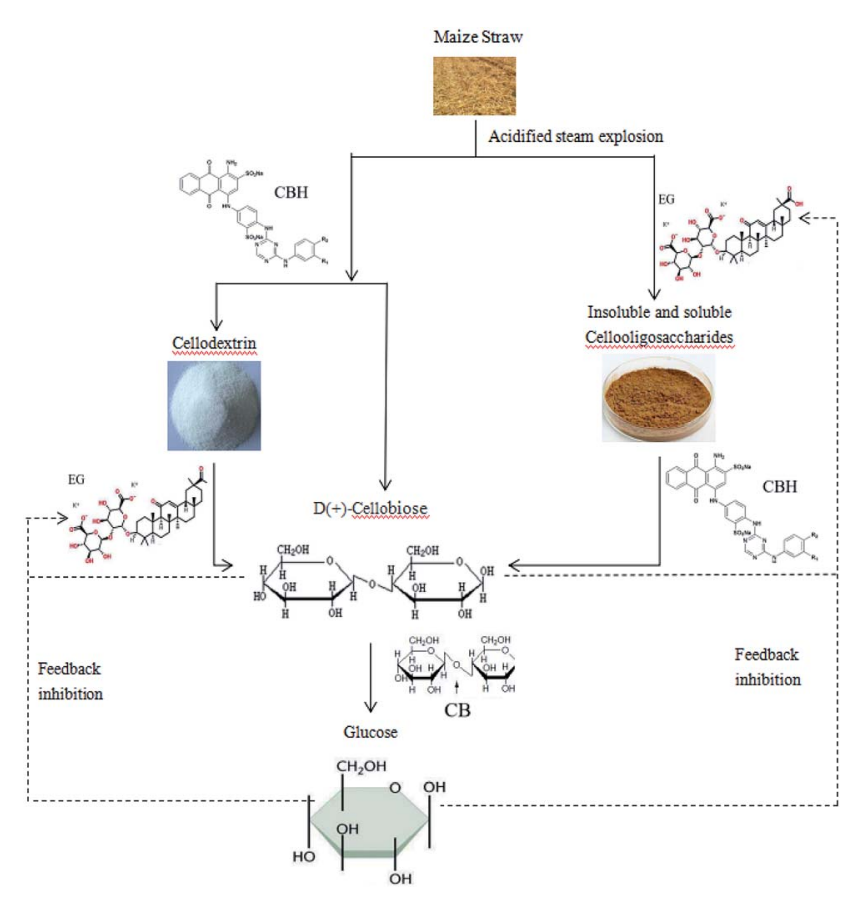

Fig. 7 Mechanism model of cellulose hydrolysis inhibition. 

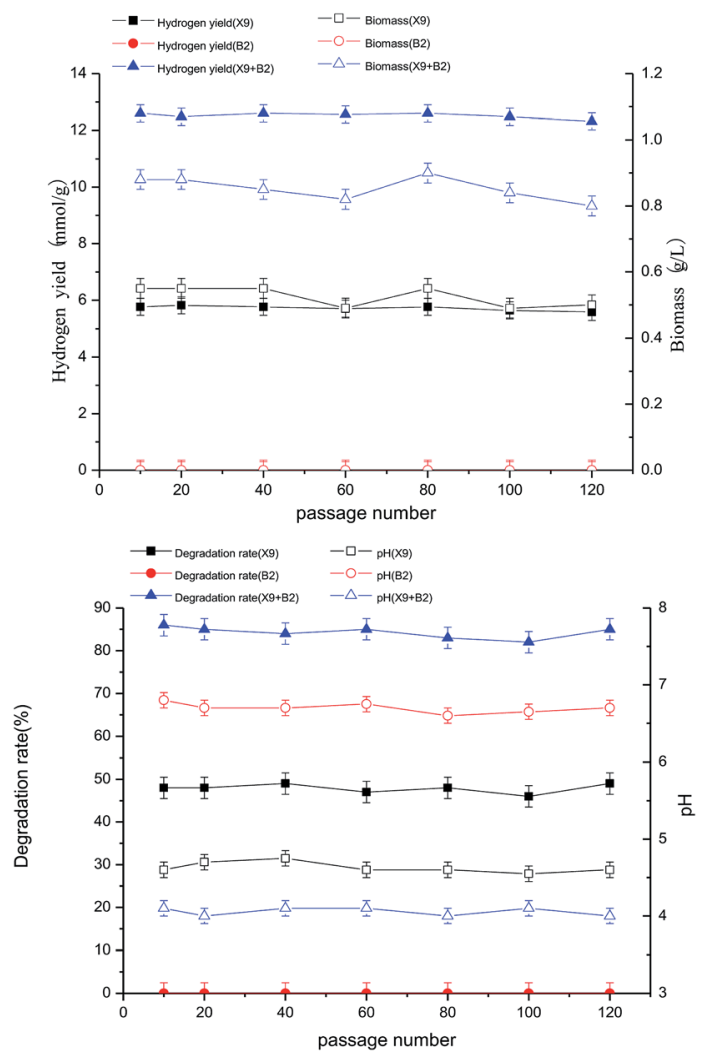

Fig. 8 The stability of cellulose degradation and $\mathrm{H}_{2}$ production by complex bacteria.

The changes in the final $\mathrm{pH}$ of different generations of complex bacteria systems were basically the same; the biggest difference was less than 0.1, and it was basically stable at 4.1. The change in $\mathrm{pH}$ was mainly caused by the degradation of the organic acid that was produced by the fermentation process of maize straw. It could be seen that there was a close positive correlation between the $\mathrm{pH}$ change for the complex bacteria and the hydrogen production by degradation of maize straw. Comparison of the changes in the final $\mathrm{pH}$ of different generations of complex bacteria systems indicated that there was good stability.

After successive subcultures and their $10^{\text {th }}, 20^{\text {th }}, 40^{\text {th }}, 60^{\text {th }}$, $80^{\text {th }}, 100^{\text {th }}$ and $120^{\text {th }}$ generations, the complex bacteria constructed by $\mathrm{X} 9$ and $\mathrm{B} 2$ could still maintain a high capacity of synergistic degradation of maize straw for hydrogen production, showing high biological activity and stability. This was closely related to the separation from the same ecological environment. The complex bacteria, to some extent, enhanced the natural biological hydrogen production process in artificially reproduced laboratory conditions. Therefore, the complex microbial community, which causes stable and efficient hydrogen production by the degradation of maize straw through fermentation, provides an experimental basis and data for the future industrialization of more complex natural lignocellulose.

\section{Conclusions}

1. In this paper, three kinds of pure strains isolated from CSTR were used: ethanol-type fermentation hydrogen-producing bacteria (B2, B19, B49), butyric acid-type fermentation hydrogen-producing bacteria (C3) and butyric acid-degrading cellulose hydrogen-producing bacteria ( $\mathrm{X} 9, \mathrm{X} 12)$ as test bacteria materials. A group of high-efficiency, hydrogenproducing complex bacteria X9 + B2 that degraded maize straw was developed by a strain combination optimization experiment. The hydrogen production capacity was much greater than that of any single strain of fermented maize straw.

2. After successfully constructing a group of high-efficiency, maize straw degrading, hydrogen-producing complex bacteria $\mathrm{X} 9+\mathrm{B} 2$, the three factors of initial $\mathrm{pH}$, substrate concentration and culture time of maize straw production were tested by a single factor. The suitable conditions for the degradation of maize straw by the complex bacteria were an initial $\mathrm{pH}$ of 6 , substrate concentration of $12 \mathrm{~g} \mathrm{~L}^{-1}$, and culture time of $40 \mathrm{~h}$.

3. Through the optimization of the model, the theoretical conditions for the hydrogen production of the complex bacteria to obtain maize straw were obtained. The substrate concentration was $11.73 \mathrm{~g} \mathrm{~L}^{-1}$, the initial $\mathrm{pH}$ was 5.98 , and the culture time was $40.42 \mathrm{~h}$. Based on the industrial production situation, the optimal solution was the substrate concentration of $12 \mathrm{~g}$ $\mathrm{L}^{-1}$, the initial $\mathrm{pH}$ of 6 and the incubation time of $40 \mathrm{~h}$. Under these conditions, the measured hydrogen production rate was $99.8 \%$ of the predicted value. The experimental values were consistent with the model optimization simulation values, and the higher hydrogen production was obtained, which indicated that the model has a certain guiding significance.

4. A quadratic polynomial mathematical model for the hydrogen production rate of maize straw degraded by complex bacteria was established. The model showed that the effects of various factors on the hydrogen production rate were in the order of initial $\mathrm{pH}>$ substrate concentration $>$ culture time.

5. Compared with single bacteria fermentation and hydrogen production, and compared with glucose as the substrate, ${ }^{8,9}$ the hydrogen production rate of the optimized composite bacteria can reach hydrogen production efficiency of 1.5-2 times greater. Moreover, the maize straw pretreated by acidification steam explosion as a substrate provides a possibility for the large-scale realization of hydrogen production from agricultural waste and has good development prospects.

\section{Conflicts of interest}

There are no conflicts to declare.

\section{Acknowledgements}

This study was supported by the State Key Laboratory Fund for Urban Water Environment and Water Resources (HC201814); the State Key Program of National Natural Science of China (71731007); and the Liaoning Provincial "Innovative Talents in Colleges and Universities" Support Project (LR2016055).

\section{References}

1 M. A. Tao, M. Chen, C. Wang, Z. Mao and M. Jiang, Int. J. Hydrogen Energy, 2013, 38, 13062-13068. 
2 K. Olaf, R. Jens, J. H. Mussgnug, D. G. Charles and H. Ben, Photochem. Photobiol. Sci., 2005, 4, 957-970.

3 S. Kim, J. Chung and J.-O. Kim, Biodegradation, 2013, 24, 753-764.

4 J. Wang and Y. Yin, Int. J. Hydrogen Energy, 2017, 42, 48044823.

5 P. Intanoo, P. Chaimongkol and S. Chavadej, Int. J. Hydrogen Energy, 2016, 41, 6107-6114.

6 T. Chookaew, S. Othong and P. Prasertsan, Int. J. Hydrogen Energy, 2012, 37, 13314-13322.

7 J. Wang and W. Wei, Int. J. Hydrogen Energy, 2008, 33, 29342941.

8 S. K. Samson and T. R. Manikkandan, Iran. J. Chem. Chem. Eng., 2017, 36, 173-181.

9 D. Li and H. Chen, Int. J. Hydrogen Energy, 2007, 32, 17421748.

10 M. Kotani, T. Koike, K. Yamaguchi and N. Mizuno, J. Cheminf., 2006, 8, 735-741.

11 C. Qiu, Y. Ping, L. Sun, S. Wang, S. Lo and D. Zhang, J. Chem. Technol. Biotechnol., 2017, 92(8), 1990-1997.

12 Y. F. Li, Y. T. Duan, F. J. Liu, L. Wang and Y. X. Wang, Adv. Mater. Res., 2011, 183-185, 31-34.

13 H. H. Cheng, L. M. Whang, M. C. Chung and K. C. Chan, Bioresour. Technol., 2016, 210, 49-55.

14 A. Ghimire, E. Trably, L. Frunzo, F. Pirozzi, P. N. L. Lens, G. Esposito, E. A. Cazier and R. Escudié, Bioresour. Technol., 2017, 248, 180-186.

15 L. I. Qiu bo, D. F. Xing, N. Q. Ren, L. H. Zhao and Y. Y. Song, Environ. Sci., 2006, 27, 810.

16 A. Adessi, M. Concato, A. Sanchini, F. Rossi and R. D. Philippis, Appl. Microbiol. Biotechnol., 2016, 100, 2917-2926.

17 J. Slots, J. Dent. Res., 2010, 83, 274-278.

18 B. Liu, Y. Jin, G. Xie, Z. Wang, H. Wen, N. Ren and D. Xing, ES Energy \& Environment, 2018, 1, 56-66.

19 E. Gutiérrez-Arnillas, M. Arellano, F. J. Deive, A. Rodríguez and M. Á. Sanromán, Bioresour. Technol., 2017, 239, 368.
20 S. Jiaxiu, A. Dong, R. Nanqi, Z. Yongming and C. Ying, Bioresour. Technol., 2011, 102, 10875-10880.

21 B. Saha, Int. Biodeterior. Biodegrad., 2016, 109, 29-35.

22 B. C. Saha, N. Qureshi, G. J. Kennedy and M. A. Cotta, Int. Biodeterior. Biodegrad., 2016, 109, 29-35.

23 E. Hong, J. Kim, S. Rhie, S. J. Ha, J. Kim and Y. Ryu, Biotechnol. Bioprocess Eng., 2016, 21, 612-619.

24 N. Q. Ren, H. Chua, S. Y. Chan, Y. F. Tsang, Y. J. Wang and N. Sin, Bioresour. Technol., 2007, 98, 1774-1780.

25 S. K. Khanal, W. H. Chen, L. Li and S. Sung, Water Environ. Res., 2006, 78, 110-117.

26 C. Badal, B. L. Iten, A. M. Cotta and Y. Victor WU, J. Biobased Mater. Bioenergy, 2005, 40, 3693-3700.

27 G. P. Philippidis, T. K. Smith and C. E. Wyman, Biotechnol. Bioeng., 2010, 41, 846-853.

28 A. Sharma, R. Tewari, S. S. Rana, R. Soni and S. K. Soni, Appl. Biochem. Biotechnol., 2016, 179, 1346-1380.

29 S. Y. Han, K. H. Han, Y. H. Jee, Y. S. Kang, H. K. Kim, J. Y. Han, Y. S. Kim and D. R. Cha, Nephrol., Dial., Transplant., 2006, 21, 2406-2416.

30 M. A. Rachman, Y. Furutani, Y. Nakashimada, T. Kakizono and N. Nishio, J. Ferment. Bioeng., 1997, 83, 358-363.

31 C. M. Pan, H. C. Ma, Y. T. Fan and H. W. Hou, Int. J. Hydrogen Energy, 2011, 36, 4852-4862.

32 A. Meinke, H. G. Damude, P. Tomme, E. Kwan, D. G. Kilburn, R. C. Miller, R. A. Warren and N. R. Gilkes, J. Biol. Chem., 1995, 270, 4383-4386.

33 P. F. Sims, M. S. Soares-Felipe, Q. Wang, M. E. Gent, C. Tempelaars and P. Broda, Mol. Microbiol., 2010, 12, 209216.

34 A. J. Day, M. S. Dupont, S. Ridley, M. Rhodes, M. J. C. Rhodes, M. R. A. Morgan and G. Williamson, FEBS Lett., 1998, 436, 71-75.

35 A. Berlin, M. Balakshin, N. Gilkes, J. Kadla, V. Maximenko, S. Kubo and J. Saddler, J. Biotechnol., 2006, 125, 198-209. 